\title{
Qualidade e volume de leite de propriedades assistidas e não assistidas por médicos veterinários no noroeste do Rio Grande do Sul
}

Genuina Dalberto; Tanice Andreatta, Luiz da Silveira Neto, Julian Scariot, Claudia Almeida Scariot, Marcos Rovani, Elisandra Salvatori

Agronegócios, Universidade Federal de Santa Maria (UFSM), Santa Maria, RS, Brasil

*Autor correspondente

e-mail: genuinadalberto@globo.com

\section{Resumo}

Visando colaborar com as políticas regionais de apoio à agricultura familiar de produção de leite, objetiva-se investigar a mesorregião noroeste do Rio Grande do Sul (RS) quanto à qualidade e o volume do leite produzido em propriedades assistidas (grupo fomento) e não assistidas (grupo controle) por médicos veterinários. A mesorregião noroeste é a de maior produção de leite do estado. Nesses casos, a dependência pela renda oriunda da bovinocultura leiteira é maior. A relevância dessa atividade se dá especialmente nas esferas social e econômica. A assistência médico-veterinária, associada à baixa escolaridade dos gestores, pode implicar em menor produtividade e qualidade do produto. Dados foram coletados entre fevereiro e maio de 2016, em 84 propriedades de leite de 22 cidades da mesorregião noroeste do RS, através de questionários formulados com questões fechadas sobre assistência médico-veterinária, volume de leite, contagem de células somáticas (CCS), contagem bacteriana total (CBT), gordura, proteína e grau de escolaridade. Os resultados foram primeiramente divididos em grupo fomento (58) e grupo controle (26). Observou-se que a maioria (38,5\%) dos produtores do grupo controle não sabia a CCS do rebanho, identificada em superior a 200.000 em $100 \%$ dos mesmos. No grupo fomento, este valor foi inferior em 3,4\% das propriedades, corroborando à constatação de apenas 19\% (11/58) conhecerem a CCS atual. As medianas de CCS (P = 0,8372) e CBT (P = $0,8745)$ não diferiram entre os grupos, enquanto que gordura $(P=0,0083)$ e proteína $(P=0,0174)$ diferiram. Houve diferença significativa entre as médias de volume de leite por mês entre o grupo fomento e o grupo controle $(\mathrm{P}<\mathrm{0,0001)}$. O grupo controle $(18 / 26)$ tem maioria com ensino médio incompleto, enquanto o grupo fomento (19/58) o tem completo. As propriedades de leite da mesorregião noroeste do RS demostramse melhores em nível de escolaridade, volume de leite produzido, gordura e proteína, quando assistidas por médicos veterinários. Entretanto, os grupos controle e fomento se igualaram em termos de valores para CCS e CBT, demonstrando serem necessários maiores esforços em prol da qualidade do leite da região. 